\title{
A STUDY OF AN OTTOMAN MARBLE ENDOWMENT PRESERVED IN TOPKAPI PALACE MUSEUM IN ISTANBUL
}

\author{
Hassanein, I. \\ Islamic dept., Faculty of Archaeology, Fayoum Univ., Fayoum, Egypt \\ E-mail: iwi00@fayoum.edu.eg
}

\begin{abstract}
The endowments of the Ottoman buildings were distinguished by the diversity of their material between paper and stone. However, the paper endowments were the official legal form of these buildings as they dealt with their financial and administrative affairs, e.g. staff and endowed places, while the stone endowments did not represent the full meaning of the endowment, but they were only a summary of paper endowments. Their decrees were usually inscribed on the stone panel and fixed in one of the walls of the building, including the name of the founder of the waqf and some endowed places without details. These stone endowments decrees have a great importance because of their material, which has not been easily affected by environmental factors. This paper aims to study a marble endowment by identifying its owner, his titles, the ways of spending, the buildings that benefited, the type of endowment and its amount, the cash units used, and the officials responsible for the endowment.
\end{abstract}

Keywords: Waqf, Ottoman, Endowment, Marble, Mosque, Gerede.

\section{Introduction}

The waqfs have been known since the beginning of the Islamic era and continued in the east and west until the end of the Ottoman era [1]. In Arabic, waqf means confinement and prohibition for a specific thing in the ownership of waqf and devoting its profit in charity to the poor or other goods. This includes the waqf on the mosques, hospitals, and madrasas or the waqfs on people such as the poor and students [2]. It was customary that, the founders of waqfs listed their waqfs in documents so as not to be changed. These documents were known as the endowments. They were written in the presence of witne- sses and noted in the books of the judiciary to gain official status [3]. The materials on which endowments were inscribed during the Ottoman period include paper, leather, and stone. Stone endowments from that period, however, in comparison with other materials, are few and do not have the full meaning of endowment, but they were often briefer than the original paper or leather endowment [4]. This was confirmed by the oldest Ottoman stone endowments; the endowment of Yakub Çelebi imaret in Kütahya 1411AD and the endowment of Bayezid Pasha Imaret in Amasya 1418 AD [3]. Additionally, other private paper 
endowments were attributed to the same buildings $^{\text {(a) }}$ [5]. The aim of the owners of stone endowments was to preserve the cont- ent of the originals written on perishable materials that might be exposed to damage due to environmental factors [4].

\section{Description and Translation of the Endowment Text \\ 2.1. Description of endowment}

The endowment (our case study), pl. (1) \& fig. (1) is made of white marble $(110 \times 70 \mathrm{~cm})$. It is preserved in the second courtyard of Topkap1 Palace in Istanbul $\left(\right.$ Reg No. 63) ${ }^{(b)}$. It was written in Ottoman Turkish by talīq script in seven lines that each of which was divided into two rectangular framed written areas ${ }^{(\mathrm{c})}$. The inscriptions indicate that the owner was an official in the palace and the endowment was to support serving some buildings outside Istanbul.

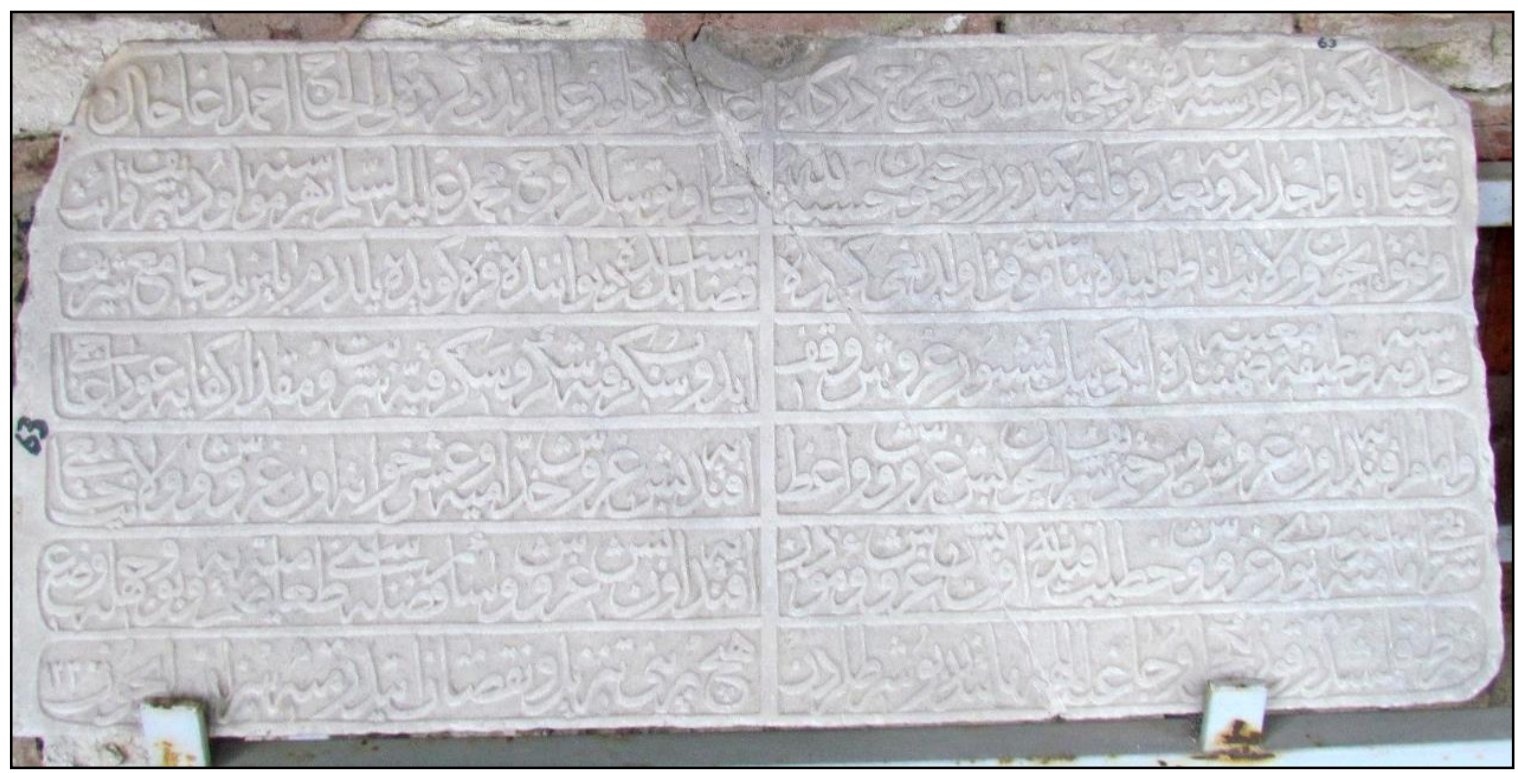

Plate (1) Shows the white marble endowment No. 63 preserved in Topkapı Palace in Istanbul

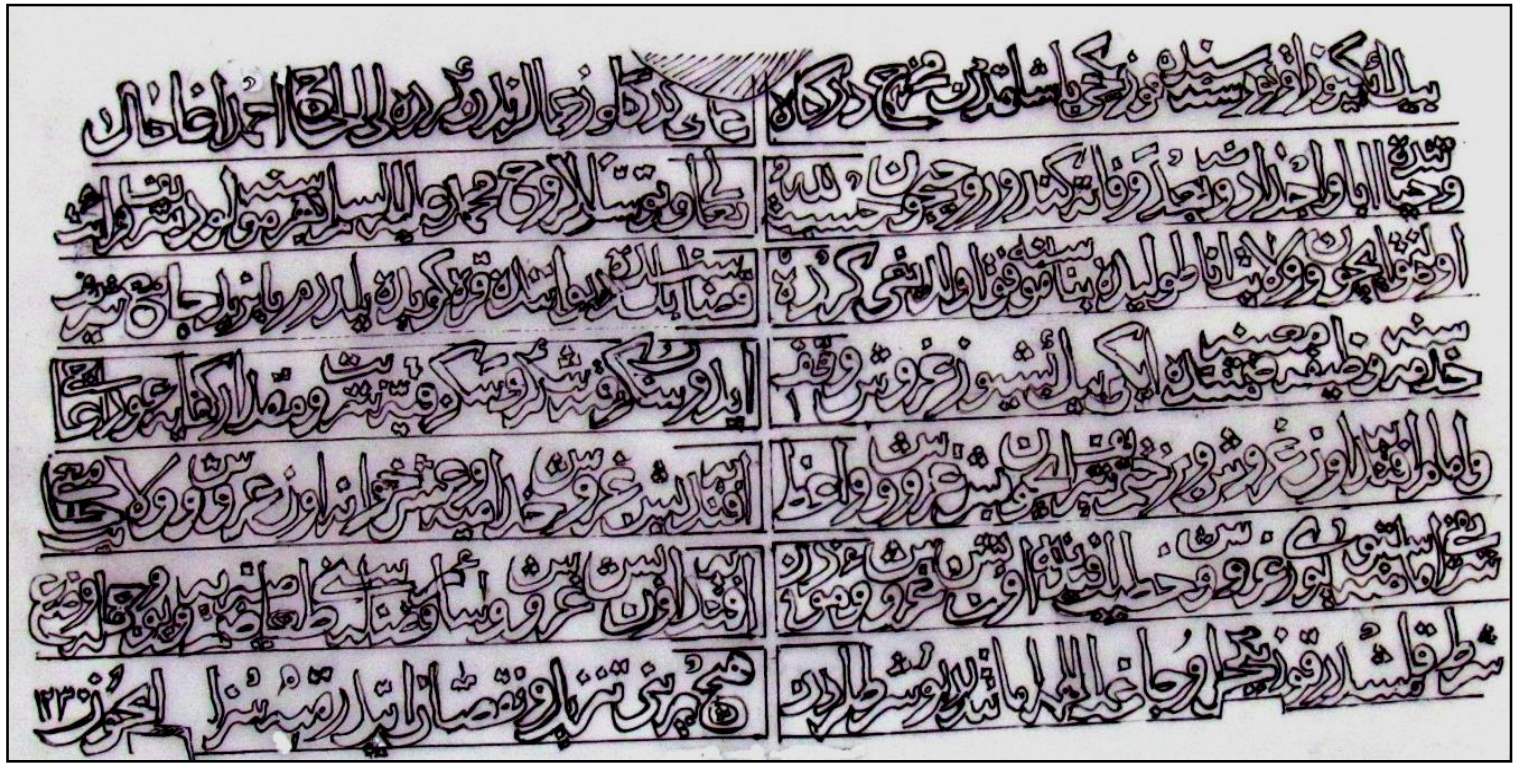

Figure (1) Shows inscriptions of endowment No. 63 preserved in Topkap1 Palace in I 


\subsection{Translation of the text of endowment}

\begin{tabular}{|c|c|c|}
\hline \multicolumn{2}{|c|}{ The Text of Endowment } & $\mathbf{L}$ \\
\hline عالى كدكلو زعمالرندن كرده لى الحاج احمد اغا حال & بيك ايكيوز اوتوزسنه سنده قوزبكجى باثنلقدن مخرج دركاه & 1 \\
\hline قرائتى وتوسلا لروح محمد عليه السلم بهر سنه مولود شريف & وحياتنده ابا و اجدادنه وبعد وفاته كندوز روحيحون حسبه لله & 2 \\
\hline قضاسنده بك ديو اننده قرة كويده يلدرم بايزيد جامع شريف & اولنمق ايجون وو لايت اناطوليده بناسنه موفق اولديغى كرده & 3 \\
\hline ايدوب سكز قيه شكر وسكز قيه شربت ومقار كفاية عود ا & وقف خده سنه وظيفئى معيته ضمننده ايكى بيك بشيوز غروش & 4 \\
\hline جامنعيه بش غروش خداميه وعشر خوانه اون غروش وولايت & ووامظ افنديه اون غروش وبر ختم شريف ايجون بش غروش & 5 \\
\hline وجهله وضنع اون بش غروش وسائر فضله سنى طعاميه ضم يه وبو & 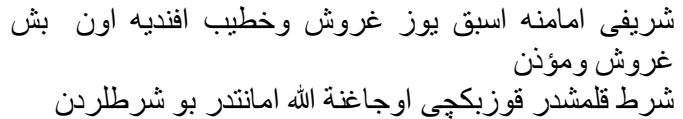 & 6 \\
\hline
\end{tabular}

\begin{tabular}{c} 
Translation of the text \\
\hline $\mathbf{1}$ In A.H1230, pilgrim Ahmed Agha from the city of Gerede, Head of the department of girls' guards \\
and one of the heads of doorkeepers of the central gate in the Palace of Topkapi, endowed \\
$\mathbf{2}$ For him during his lifetime and after his death and for his fathers and grandfathers for the sake of \\
Allah the Almighty and the soul of his prophet Mohamed peace be upon him every year in the birth \\
of the prophet for reading \\
$\mathbf{3}$ The holy Quran to reconcile him in completing his building in Anatolia, for serving the Mosque of \\
Yuldirim Bayezid located in the Beg Divan in the village of Karaköy in the city of Gerede \\
$\mathbf{4}$ 2500 piastres, 8 ounces of sugar, 8 ounces of sherbet and sufficient quantity of incense \\
10 piastres for the imam and 5 piastres for each completion of the Quran, 5 piastres for the \\
preacher, 10 piastres for the servants and the readers of one-third of the Quran and for the \\
former imam of the holy mosque in the province of Anatolia \\
$\mathbf{6}$ 100 piastres, 15 piastres for the khatib, 15 piastres for the muezzin, the remaining to be spent on \\
feeding the poor and needy according to these conditions \\
$\mathbf{7}$ This endowment was preserved in the security of the department of girls' guards to apply it \\
without any want of those conditions in A.H 1230
\end{tabular}

\section{The Owner of the Endowment; His Identity and Position Titles}

This endowment is attributed to a person called Ahmed Agha. According to the titles men-tioned, he was one of the officials in Topkap1 Palace. No direct account of his career was found. By searching in the Ottoman registers that include most of the names of the employees who served in the Ottoman Empire and their functional positions, a person was found and he was called Ahmed Agha who was brought up in the inner department in Topkapı Palace and was also known as Enderûn ${ }^{(\mathrm{d})}$. He held some positions in the Palace, such as a steward of the campaign chamber (seferli oda Kethüdası) in AH 1230/ AD 1815. Later, he retired and worked as a guard of the palace gates and was given the title of Kapıcıbaşlık or the chief of door keepers [6]. Clearly, there is a match here between the name in the endowment and the name in the Ottoman registers, including the date and the title, i.e. kapıcıbaşlık or the chief doorkeepers. Hence, Ahmed Agha the owner of the endowment was the same person whose name mentioned in the Ottoman registers who was brought up and held positions in the Palace of Topkap1. The titles mentioned in the endowment show that Ahmed Agha held more than just the position in the palace as he was entitled by; - Közbekçi, i.e. head of the department of girls' guards [7-9]. There was a department of that name with a private building next to the gate of the Imperial Mint (Darphane-i Âmire) in the first courtyard of the Palace although it is no longer extant. The name came from a team mentioned in some stories during 
the period of Sultan Mehmet the Conqueror (1451-1481), relating how one day one of the maids odalisques tried to escape from the harem at the Palace but was arrested by someone in a place full of sycamore trees. He told the chief black eunuch, known as Darüsaade Ağası, and delivered her to him. The chief black eunuch asked him about the reward he wanted from the sultan and he asked for a building to be established next to the Palace Mint for him to serve in. The sultan agreed and established a place that carried the name of Közbekçi. At first, the function of this department was the protection of the palace. Later, it was altered to be a place for changing and keeping private clothes and the clothing of sultan, as well as of the harem and treasury officer in times of promenading. This department continued until it was annulled with the Janissaries in AD 1830-1831. Some 50 or 60 persons with the title Közbekçi retired with a suitable pension [9]. Ahmed Agha, the owner of this endowment, was the head of this department and subsequently became the head of coffee makers (khaveci) of the sultan's sons in the palace [10]. - Gedekli or Gedeklo, i.e. the owner of excellence or preference. One of the distinguishing epithets mentioned in the endowment that was given to old governmental officials. It was used from the $16^{\text {th }}$ century until the begin-ning of the $20^{\text {th }}$ century [11]. Holders of this title were characterized by their clothes with a cloth belt decorated with gold and silver around their waists called Saraser [9]. The elderly Ahmed Agha was entitled this epithet because of holding different positions in the palace. - Zoamaa, i.e. leadership. This title is related to the aforem-entioned titles and names such as Mehreç-Dergah Ali, i.e. the head of the doorkeepers of the central gate in the palace. The Palace of Topkapı comprised three main gates. While, the first was the Imperial Gate (Bâb-1 Hümâyûn), the second was the Salutation Gate (Bâb-üsSelâm) or the central gate known as Dergah Ali (the Sublime Gate), and the third one was the Felicity Gate (Babü's-Saade). The first and second gates were guarded by a number of doorkeepers belonging to the outer department known as Birün in the palace, while the third one was guarded by Darüsaade ağası [12]. The head of the first and second gates was called Kapicilar Kethüdas1 or steward of the doorkeepers. He was the chief commandant of all the doorkeepers. His tasks involved attending meetings of the sultan and grand vizier [13]. He supervised a number of doorkeepers called as Kapıcı başları or the chiefs of doorkeepers who were the second in command after the steward of the doorkeepers and acted on his behalf of in appointments retirement doorkeepers as well as carrying important and secret decrees to the feudal governors in different provinces. Furthermore, they were appointed ambassadors in foreign countries and were therefore responsible for diplomatic missions. They were chosen from the doorkeepers themselves, silahdars (arms-bearer), and gardeners who work in the inner department of the palace. This system of appointing continued until the dissolving of the Janissaries in 1826 under Sultan Mahmud II, after which it was restricted to the sons of princes and pashas [13]. The numbers of heads of doorkeepers differed from time to time throughout the Ottoman period. The position of Kapıc1 başları in the $15^{\text {th }}$ century, in the era of Sultan Mehmet the Conqueror, was held by only one doorkeeper. At the beginning of the $16^{\text {th }}$ century, there were four doorkeepers and increased to ten by the end of the century. By the beginning of the $17^{\text {th }}$ century, they were between thirteen and twenty one doorkeepers. Fifty years later, there were twelve. During the first half of the $18^{\text {th }}$ century, they were sixty and at by the end of the century, the number increased to one hundred and fifty [12]. The 
oldest of them was called Başkapıcı Başı or chairperson of doorkeepers. Their salary reached 159 akçe at the end of $17^{\text {th }}$ century and, in addition, many held high ranks such as the head of the sanjak or even the position of vizier $[12,13]$. This situation continued after the end of the Janissary system but it witnessed some changes. Only thirty of them continued with the remaining being retired with a

\section{Aspects of Spending}

Spending on the celebration of Prophet Mohamad's birthday was significant since it grew in importance as one of the Ottoman protocols from the reign of Sultan Süleyman the Magnificent (15201566). It became an official feature of the calendar during the reign of Sultan Murad III (1574-1595). At first, the celebration was held in the Mosque of Ağalar in Topkapı Palace. Later, it was held in one of the greatest Sultans' mosques such as the Mosque of Sultan Ahmed, Valide Sultan Mosque, and Eyüb Sultan Mosque. Under Ottoman protocol, invitations were sent to the men of the state a day before the event and when the mosque had been chosen the celebration was held by reading the Holy Quran [3,14]. Spending was allocated to the workers such as

\section{Structures of The Endowment}

The endowment included spending on workers in two mosques in the city of Gerede, located in the province of Bolu in central Anatolia halfway along the road between Ankara and Istanbul. This city has an ancient history from the Roman, Byzantine, and Islamic eras [16].The period of the Ottoman Sultan Y1ldirım Bayezid (1389-1402) was one of the interesting times in the history of Bolu and its cities such as Gerede ${ }^{(e)}$. This was due to the great architectural development that took place and the many early Ottoman buildings attributed to him, including Bayezid Mosque, pension of 300 piastres. They were dubbed by names such as سر البوابين ركاب همايون Sr Al-Bawabeen Rekab Hamayoni Melokna or they were responsible for the service of sultans' rides as they belonged to the master of the stable, not to the doorkeepers' steward [13]. Ahmed Agha was probably given this title after retirement from working as Közbekçi.

imams, muezzins, preachers, khatibs, and servants of mosques of the city of Gerede. Although they were not of high rank, they were greatly appreciated in society. The function of the imam was to lead prayers; the khatib delivered the speeches of Friday, Eid Al-Adha, and Eid Al-Fitr; the preacher gave religious lessons in the mosque after prayers; the muezzin called for the time of prayers and intoned invocations and the Quran [15].Their employment in mosques was on the order of the Seyhülislam, (the head of the ulema) in Istanbul, while the workers in the mosques outside Istanbul were employed on the order of Kadiaskers (military judges) according to the location of the mosque [15].

Orta Hammam, Mosque and Bath Bayezid in Mudurnu, Mosque and Bath Bayezid in Eski-Çağa, Mosque and Bath Bayezid in Gerede [17]. * The first mosque mentioned in the endowment is the mosque of Yıldırım Bayezid in the village of Karaköy, Gerede. Although it bears the name of the sultan Bayezid, its founder was Ahmed Agha, the owner of the endowment. The mosque was named after the Ottoman sultan probably as a blessing, whereas most of the buildings of Bolu and Gerede bore the name of Sultan Yildırım Bayezid when he was appointed as governor for 
this province before becoming sultan. This mosque was founded in $\mathrm{AH} 1231$ but the only remaining part from this phase is the lower part of its minaret standing today to a height of $2.65 \mathrm{~m}$. [18], as it was destroyed by an earthquake in 1944 after which it was rebuilt by the people of the city. * The second mosque is the Mosque of the Wilayat al-Sharif. This is a mosque of Sultan Yildırım Bayezid located in the district of EskiÇağa, Gerede. It was estab-

$$
\text { الاوقافع الثريف للمرحوم والمغفورله السلطان بايزبي خان الواقع بقصبة جاغا، وهومن الاوقاف الملحقة بنظارة }
$$

al-Sharif mosque for the deceased, forgiven Sultan Bayezid Khan located in Çăga district is one of the endowments attached to imperial endowments. The remaining original parts were wall foundations with a thickness of $1.20 \mathrm{~m}$. $[19,20]$. After an earthquake in 1944, it was rebuilt by the people of the area following closely its original shape. It measures $8.35 \times 5.25 \mathrm{~m}$ with a simple roof. At its northern part, there is a covered riwaq in front of the prayer hall and it has

\section{Type of Endowment}

Endowments varied between monetary and commodities. The latter was represented by materials such as sugar, sherbet made from honey and sugar or fruits such as oranges and lemons [22], as well as a quantity of incense. Monetary endowment involved financial sums lished in AD 1388 by Sultan Yildırım Bayezid. The attribution is confirmed by the titles ment-ioned in the register of endowments naming Ylldırım Bayezid in the district of EskiÇağa al-Camii al-Sharif (Great Mosque). Further-more, no other mosque was built by Sultan Yıldırım Bayezid in Gerede or Bolu entitled al-Sharif ${ }^{(f)}$. This text in the register of endo-wments reads as follows: two windows on both sides [20]. This mosque was described in the register of Salname that explained in detail the economic, social, and historical conditions of Gerede city in AH 1334 / AD 1916, before the earthquake, as follows: The City of Gerede has 9 mosques; the oldest of them was founded with a bath by Sultan Ylldırım Bayezid. al-Sharif mosque was one of the greatest charity works and foundations assigning a place in paradise for Yıldırım Bayezid [21].

given to the workers of those mosques such as imams, muezzins, and orators, as well as spending the remaining money on feeding the poor and needy during the celebrations of the Prophet Mohamad's birthday or reading the Holy Quran.

\section{Monetary Units and Quantification Used}

-Kuruss, piastres. One of the common silver coins in the Ottoman era, the origin of this word was the Latin grossus, which was used for different types of dinar minting for the first time by European rulers in the $13^{\text {th }}$ century [23]. It is thought that the first mention was at the beginning of the era of Sultan Süleyman II (16421691). The rate of exchange of an Ottoman
Kuruş was 30 halves of silver during the first half of the $16^{\text {th }}$ century. They were known in the docu-ments of legality court by coefficient kuruş and numeral kuruş [23,24]. - Kıyye, Ounce, one of the units used in the Ottoman period, known also as an Oka, equal to 400 dirhams [9] and weighing 1283 grammes [25]. 


\section{Officials Responsible of Endowment Implementation}

Implementation was assigned to the Topkapi whose head was responsible for department of Közbekçi in the place of

all its affairs.

\section{Conclusion}

The study illustrated that this marble endowment represents a summary of other paper endowments and includes all the details related to the mosques located in the city of Gerede. It shed light on the owner of the endowment, his name, position, titles, and the places where he worked by connecting what was mentioned in endowment inscriptions with what was written in the Ottoman records, especially as no explicit translation was found for the owner of the endowment. The study highlighted the names of the architectural buildings that related to the endowment and revealed their locations and current status. The study also showed that Yıldırm Bayezid Mosque located in the Village of Karaköy could be attributed to the owner of the endowment, not to the Ottoman Sultan Yıldırm Bayezid. Furthermore, it illustrated the amount of the endowment and its quality, the monetary units and quantification used during this period, and the officials who were responsible for the implementation of the endowment.

\section{Endnotes}

(a) There is a paper endowment of Bayezid Pasha Imaret in Amasya preserved in the archive of the Prime Minister. It was written by Naskh script and dated 11 Zulhijja A.H 820 / January A.D 1418. It is $174 \times 32.5 \mathrm{~cm}$, the font of writing is $28.5 \mathrm{~cm}$, and the number of lines is 109. Its upper part includes missing certification statement followed by the content of endowment that begins with Quran verses; a description of Amasya, places, villages and mills endowed in details, and the workers and the conditions in details. The lower part includes witnesses names arranged in 6 lines; about 38 witnesses. On comparing the paper and stone endowments, it is found that the stone endowment was a brief for the paper endowment and mentioned only some endowed places not all. Yardim, A., (2004). Amasya Kaya Kitabesi, Beyazit Paşa Imareti Vakfiyesi ( Arock Inscription in Amasya, The Endowment of Imaret Bayezid Paşa), Ankara.

(b) http://www.ottomaninscriptions.com/ verse .aspx ?ref=list\&bid=1265\&hid $=49$ 67, 20-4- 2017.

(c) The inscriptions of the endowment were written in the Ottoman Turkish language, which was specifically used in the writings of the endowment since the middle of the $16^{\text {th }}$ century after promulgating of ferman from the Ottoman Sultan Suleiman I in AH 960 / AD 1552: 1553 to write the endowments in Ottoman Turkish language. The calligraphy in used in the inscriptions of endowments varied and changed over time between naskh, thuluth, and riq'ah. Tak, E., (2009). Diplomatik bilimi bakımından XVI.-XVII. Yüzyıl kadı sicilleri ve bu sicillerin ihtiva ettiği belgetürlerinin form özellikleri ve tanımlanmast (16-17 $7^{\text {th }}$ century Qadi registers according to the rules of diplomatics science and the description and structural characteristics of the document types recorded in these registers), Ph.D, Information and Records Management dept., Research Institute of Turkology, Marmara Univ.,Turkey.

(d) Enderun or inner section in Topkap1 Palace was founded in the first half of the $15^{\text {th }}$ and completed its organization in the second half. Enderun can be defined as the administrator school of the Ottoman State; it was aimed to train the ablest children for leadership positions, either as military leaders or as high administrators to serve the Empire. The children who joined this school studied Islamic sciences, incl- 
uding Arabic, Turkish, and Persian languages; Positive sciences; mathematics, geography, history, law, and administration; the customs of the Palace and government issues; voca-tional studies, including art and music; and Physical training, including weaponry. By the end of the Enderun School, the graduates were able to speak, read, and write at least 3 languages; understand the latest developments in science; have at least a craft or art; and excel in army command as well as in close combat skills. Kurban, S., (2017). Topkapi palace as a moral and political institutional structure in the Ottoman palace organization, Int. J. of Humanities \& Social Science, Vol. 7, No. 3, pp:101108. Corlu, S., Burlbaw, L., Capraro, R., Corlu, M. \& Han, S., (2010). The Ottoman palace school Enderun and the Man with Multiple Talents, MatrakçıNasuh, J. of the Korea Society of

\section{References}

[1] Qahf, M., (2000). Al-waqf al-islami, Tatawurah, idratuh, tanmiatuh (Islamic waqf, development, managment and its improvment), Dar Al-Fikr, Damascus.

[2] Mahmoud, A., (2013). Wathiqat waqf shariyye Osmaniya, Dirasat athria hadaria wa wathaaqiye (An Ottoman legal endowment, archeological, civilized and documentary study), Journal of Faculty of Arts, Qena, South Valley Univ., Vol. 41, pp: 100:169.

[3] Şeker, M., (1999). Vakfiyelerin Türk Kültürü Tarihi Bakımından Özellikleri, Vakfiye ve Özellikleri (The Features of endowments in Turkish culture from the historical point: The endowment and its features), The History of Turkish Civilization, Anadolu Univ., Turkey.

[4] Kunter, H., (1938). Türk Vakıfları ve Vakfiyeleri üzerine mücmel bir etüd (A general study for the Turkish Waqfs and endowments), Journal of Vakıflar, Vol. I, pp: 103-129.
Mathe-matical Education Series D: Research in Mathematical Education, Vol. 14, No. 1, pp: 19-31.

(e) There were other cities as Markaz, Gagha, Mengin affiliated to Bolu province. Güler, M., (1998). Bolu İli Gelenkesel Konut Mimarisi Üzerine Bir Araştırma ve koruma Önerileri (A research and defen offer on traditional house architecture of Bolu City), M.Sc., Architecture dept., Institute of Sciences, Yıldız Teknik Univ., Istanbul.

(f) Bolu province included, at the beginning of $20^{\text {th }}$ century according to the Salname's register, a lot of mosques that reached 84 and most of them were founded in the era of Yildirım Bayezid. Birgören, H., (2008). Müstakil Bolu Sancă̆ Salnamesi, Hicri 1334, Miladi1916, (The Salname of Bolu province AH 1334, AD 1916), Bolu Research Center, Vol. I, Bolu.

[5] Yardım, A., (2004). Amasya kaya kitabesi, keyazit paşa Imareti vakfiyesi (A rock inscription in Amasya: The endowment of Imaret Bayezid Paşa), Amasya Valiliği Kulü Pub., Ankara.

[6] Süreyya, M., (1996). Sicill-i Osmani 1 (The Ottoman Register 1), Vakıf History Publictions 30, Istanbul.

[7] Al-Khatib, M., (1996). Muejam almustalahat we al-alqab al-tarikhia (The glossary of historical terms and titles) Al-Resale Foundation, Beirut.

[8] Saban, S., (2004). Al-awqaf fi Turkye, (The waqfs in Turkey), Journal of AlFaisal, Vol. 332, pp: 62-67

[9] Pakalın, M., (1993). Osmanl Tarih Deyimleri ve Terimleri Sözlüğü, (The Dictionary of Ottoman Terms and Expressions), Vol. II, Ministry of National Education Press, Istanbul.

[10] Cenkmen, E., (1948). Osmanlı Sarayı ve Klyafetleri (Ottoman Palace and its 
Cloths), Turkey Publishing House, Istanpul.

[11] Saban, S., (2000). Muejmal-mawsuei lil mustalahat al-osmaniya al-tarikhia (The Encyclopedical dictionary of Historical Ottoman Terms), King Fahad National Library, Riyadh.

[12] Uzunçarşı1l, İ., (1984). Osmanlı devletinin saray teşkilatı (Palace Organization of the Ottoman State), Türk Tarih Kurumu Pub. House, Ankara.

[13] Özcan, A., (1998). Kapıcı (Door keeper), The Islamic Encyclopedia, Vol. 24, Türkiye Diyanet Foundation, Ankara.

[14] Efendi, E.,(1979). Osmanllarda Töre ve Törenler (The Ceremonies and customs in the Ottoman Empire), Kitapç1lık Basin Sanayi ve Ticaret A.Ş pub, Istanbul.

[15] Al-Shennawi, A., (1980). Al-dawlat al-Osmanniya (The Ottoman State), Vol. I, Cairo Univ. Press, Cairo.

[16] Dikmen, Ç. \& Toruk. F., (2015). Gerede Yukarı hamam restorasyonuna ilişkin de ğerlendirmeler (Evaluation of restoration of Gerede Yukarı bath), in: Sağöz, A. \& Alel, J. (eds.) Symposium on Strengthening and Preserving Historical Buildings and Cultural Heritage -5, Erzurum, pp: 431-555.

[17] Dolma, M., (2006). 875 Numaralı Şeriye Sicil Defterine göre Tanzimat-I Hayriye'nin ilk Ylllarinda Bolu 18411844) (Bolu in the legal register number 875 in years 1841-1844), M.Sc., Modern History dept., The Social Sciences Institue., Abant İzzet Baysal Univ., Bolu.

[18] Erkoçoğlu, F., (2000). Gerede'de Osmanlı kalma vakıflar ve tarihi eserler
(The remaining Ottoman waqfs and historical monuments in Gerede), in: Aycan, I \& Ünlüol, K. (eds.) The Symposium of Gerede from past to present, Gerede, pp: 81-103

[19] Ayverdi, E., (1966). Osmanll mimarisinin ilk devri (The first era of Ottoman architecture), Vol. I, Baha Press, Istanbul.

[20] Vakıflar Genel Müdürlüğü., (1977). Türkiye'de vaklf abideleri ve eski eserler II. (The waqf buildings and ancient monuments in Turkey), Vol. II, Publications of the General Directorate of Waqfs, Ankara.

[21] Birgören, H., (2008). Müstakil Bolu sancağl salnamesi, Hicri 1334, Miladi 1916, (The Salname of Bolu province AH 1334,AD 1916), Vol. I, Bolu Research Center, Bolu.

[22] Ohsson, M., (1980). XVIII. yüzyıl Türkiye'sinde örf ve adetler (The Customs and Traditions in Turkey in XVIII century), Tercüman Publications, Istanbul.

[23] Al-Sawy, A., (2001). Al-nkoud almutadawala fi misr al-Osmaniya, (The coins used in Ottoman Egypt), The Center of Arab Civilization, Cairo

[24] Özcan, R., (2016). Osmanlı devleti'nde XVII. yüzyılda yapılan sikke tashihleri, (Money devaluation in the Ottoman empire in $17^{\text {th }}$ century), Journal of Studies in Turcology, Vol. 40, pp: 237266

[25] Hinz, F., (1970). Almakayil wa alawzan al-islamiyya (Islamic weights and measures), Amman Univ. Publictions, Jordan. 